\title{
Career Competencies and Perceived Work Performance*
}

\author{
Yong-Ho PARK ${ }^{1}$
}

Received: March 10, 2020 Revised: April 07, 2020. Accepted: May 05, 2020.

\begin{abstract}
Previous studies have suggested that individuals need to invest in the accumulation of career competencies. To demonstrate how to acquire career competencies, a model consisting of the knowing why, knowing how, and knowing whom competencies was actively discussed in the previous studies. This study seeks to identify the relationships among these competencies based on three ways of knowing, and their effects on perceived work performance. Furthermore, this study tried to identify the importance of each of these competencies in predicting perceived individual performance in the business workplace environment. The findings showed that the knowing why, knowing how, and knowing whom competencies all have a statistically significant positive influence on perceived individual work performance. Also, the study results showed the relative importance of the three competencies for perceived work performance. Specifically, the study results showed that the effects of the knowing why and knowing whom competencies are greater than the effect of the knowing how competency. The theoretical and practical implications of the study results were provided, including empirical evidence of the validity of the career capital model, the appropriateness of the career competency model based on the three ways of knowing, and assignment of resources for the acquisition of career competencies.
\end{abstract}

Keywords : Career Competency, Career Capital, Intelligent Career Competency, Perceived Work Performance

JEL Classification Code: M12, M53, M54

\section{Introduction}

Due to the new nature of work, the career landscape has changed. The new nature of work is related to the various work arrangements that are now in existence as well as to individuals' perceptions of the meaning of work and the new technologies used for work (Kang et al., 2016; Lee \& Kim, 2019). In this career environment, new careers focusing on unpredictability have been discussed practically and theoretically in the last two decades. The new careers have underscored mobility (Arthur, Inkson, \& Pringle, 1999;

*This study was supported by Incheon National University Research Grant.

${ }^{1}$ First Author and Corresponding Author. Associate Professor, Department of Creative Human Resource Development, College of Social Science, Incheon National University, Korea [Postal Address: 119 Academy-ro, Yeonsu-gu, Incheon, 22012, Korea] Email: yhpark@inu.ac.kr and yxp122@gmail.com

(c) Copyright: The Author(s)

This is an Open Access article distributed under the terms of the Creative Commons Attribution Non-Commercial License (http://Creativecommons.org/licenses/by-nc/4.0/) which permits unrestricted noncommercial use, distribution, and reproduction in any medium, provided the original work is properly cited.
Arthur \& Rousseau, 1996), self-directedness (Hall, 2002), changing pattern (Mainiero \& Sullivan, 2005), and career capital accumulation (DeFillippi \& Arthur, 1994). The new careers differ from the traditional careers defined by upward movement based on the long-term psychological contract with an organization. In the modern career environment, it is the individual who is making imperative decisions for his/her successful career development. Especially, as the responsibility for career development falls on the individual, the individual needs to acquire and invest in career competencies consisting of the skills, aptitudes, and interactions needed for successful work performance (Colakoglu, 2011).

The previous relevant studies suggested that the individuals in the current career environment need to be career capitalists accumulating career competencies for career success (Cappellen \& Janssens, 2008; Parker, Khapova, \& Arthur, 2009; Sturges, Simpson, \& Altman, 2003). Such career capitalist concept is the basis of the intelligent career theory, which has been discussed for about a quarter of a century now (DeFillippi \& Arthur, 1994). The intelligent career is the application of Quinn's (1992) intelligent firm theory to individuals' career investment 
behaviors (Parker, Khapova, \& Arthur, 2009). According to the previous discussion of the intelligent career, an individual needs to invest his/her resources in acquiring competencies based on three ways of knowing. These three different ways of knowing have been regarded as the critical aspects of career competency in the modern career environment (Suutari \& Mäkelä, 2007). The previous studies showed that the three aforementioned career competencies are the critical predictors of many work performance aspects in various research settings (Beigi, Nayyeri, \& Shirmohammadi, 2020; Beigi, Shirmohammadi, \& Arthur, 2018; Colakoglu, 2011; Dickmann \& Mills, 2010; Eby, Butts, \& Lockwood, 2003; Suutari \& Mäkelä, 2007; Zikic \& Ezzedeen, 2015).

Even though the previous studies, however, took pains to delineate the intelligent career model, there are very few empirical approaches explaining the appropriateness of the model. Also, there have been few studies that empirically investigated the impact of three competencies on the workplace outcome variables. As such, this study investigated the effects of the career competencies on perceived work performance. Also, this study aimed to find the relative importance of the three competencies, which are based on the three ways of knowing in predicting perceived work performance. Towards these ends, this study collected data from a sample group in the South Korean financial industry. The results of this study may provide an empirical evidence of the appropriateness of the intelligent career model as well as a practical suggestion for allocating resources for enhancing work performance. Starting with a review of the previous literature on the three ways of knowing, this study suggested four hypotheses regarding career competencies and perceived work performance.

\section{Literature Review}

\subsection{Career Competency}

It is considered that the resource-based approach is effective in conceptualizing how to manage an individual's career in the modern career environment (Jones \& DeFillippi, 1996; Jones $\&$ Lichtenstein, 2000). The initial writings on the competencybased view of the individual career (DeFillippi \& Arthur, 1994) were built on the academic literature on the knowledge-driven firms' core competencies, including their culture, know-how, and networks. In the modern career environment, an individual's responsibility for managing his/her own career is imperative for career success (Kuijpers, Schyns, \& Scheerens, 2006). In other words, the individuals in the knowledge economy need to act proactively rather than act like subordinates of the organizations employing them (Ahn \& Park, 2016; Beigi, Shirmohammadi, \& Arthur, 2018; Colakoglu, 2005, 2011; DeFillippi \& Arthur, 1994; Park \& Park, 2019; Suutari \& Mäkelä, 2007; Zikic \& Ezzedeen, 2015).
Inkson and Arthur (2001) argued that individuals' resource-based perspective on career development can be described as the accumulation of career capital. Based on this approach, in the modern career environment, individuals should cultivate career competencies to secure their development and enhance their employability (Jones \& Lichtenstein, 2000; Lichtenstein \& Mendenhall, 2002). Cultivation of career competencies is related to the investment of time and effort in career development activities. This investing behavior is an approach similar to individuals' investment in financial opportunities. The previous studies argued that the individuals in the modern career era need to be career capitalists (Arthur, Inkson, \& Pringle, 1999: Inkson \& Arthur, 2001). According to DeFillippi and Arthur (1994, 1996), career competencies based on the "intelligent career" are needed to be a "career capitalist".

The intelligent career, which articulates the need for individuals to take responsibility for their own careers, depends on three ways of knowing including knowing why, knowing how, and knowing whom. These three ways of knowing point to three individual-level competencies (Arthur, Claman, \& DeFillippi, 1995). Recently, Arthur et al. (2017) used 'why, how, and with whom' to describe the three ways of knowing. These three ways of knowing reflect the different forms of knowing accumulated through work experience. Also, these three career competencies were found to be compatible with the other models of career competencies and other measurement scales (Akkermans et al., 2012). This is because career competencies are accumulated not only from one's experiences in a single organization, but also from one's whole career (DeFillippi \& Arthur, 1994). In other words, these three competencies influence one another in the accumulation of career capital. In recent studies, the intelligence model was examined using diverse research populations. For example, Colakoglu (2011) used an intelligent career model with data obtained from graduates of business colleges, and Francis-Smythe et al. (2015) conducted a qualitative study using in-depth semi-structured interviews of 22 entrepreneurs in the high-tech industry. The study results showed that, through the continuous cycle of interrelationships among the three career competencies, career capital accumulation was achieved. Beigi, Nayyeri, and Shirmohammadi (2020) investigated the intelligent career model with female taxi drivers in Tehran as study subjects. Also, Beigi, Shirmohammadi, and Arthur (2018) used the concept of intelligent career capital to identify the career success factors described by 28 distinguished academics and eight of their spouses. The fact that various samples have been used to obtain study results based on the concept of an intelligent career may show its appropriateness in the modern career environment. 


\subsection{Knowing Why and Work Performance}

The knowing why competency is related to individuals' perception of the meaning or purpose of work. Therefore, identity, followed by the individual's calling, career interest, perceived meaning of work, motivation, and career planning based on his/her own will, are highly connected to the knowing why competency (Arthur, Inkson, \& Pringle, 1999; Cappellen \& Janssens, 2005; DeFillippi \& Arthur, 1996; Hall, 2002, 2004: Jones \& Lichtenstein, 2000; Parker, Khapova, \& Arthur, 2009; Wrzesniewski, 2002). Of course, this knowing why competency can be developed with organizational support like human resource development strategies or human resource management systems (LipsWiersma \& Hall, 2007; Yoon, Kim, \& Eom, 2019). With this competency, individuals may be able to discover their respective career identities and future work life directions as well as the competency's implications for developing new knowledge and relationships, for doing their jobs better (Beigi, Shirmohammadi, \& Arthur, 2018; Eby, Butts, \& Lockwood, 2003). According to DeFillippi and Arthur (1994), sense-making through career competencies may involve work or non-work identification.

The previous studies identified the effects of the knowing why competency on work performance. The findings of such studies may highlight the value of developing and managing the knowing why competency in the business career environment. Colakoglu (2011) found that the knowing why competency affects the subjective career success with the mediation effects of career autonomy and career insecurity. Regarding perceived career success, Eby, Butts, and Lockwood (2003) also identified the knowing why competency as having the biggest influence among the three career competencies. Such study also found that the knowing why competency could predict organizational internal marketability. Akkermans et al. (2012) found that career competencies related to the knowing why competency, including reflection on one's motivation and qualities, self-profiling, and career control, have statistically significant relationships with work performance. FrancisSmythe et al. (2012) even found that the career competency related to goal setting and career planning has statistically significant effects on income. The present study followed the previous studies' findings; therefore, the following hypothesis was proposed:

Hypothesis 1. The knowing why competency may positively influence perceived work performance.

\subsection{Knowing How and Work Performance}

The knowing how competency concerns career-related knowledge and skills (DeFillippi \& Arthur, 1994). The target question of this career competency is "How do I work?" To invest in this career competency, individuals may develop the expertise, knowledge, and skills required for successful performance in the labor market (Arthur, Khapova, \& Richardson, 2017). Traditionally, the knowing how competency can be developed through formal learning in and outside organizations. Availing of informal learning opportunities, however, has been actively discussed as the proper approach for acquiring the knowing how competency in modern business workplace environments in which transportable and flexible abilities across organizational boundaries are important (Eby, Butts, \& Lockwood, 2003; Parker, Khapova, \& Arthur, 2009). Furthermore, the expertise, knowledge, and skills needed for the knowing how competency may have an explicit or tacit format (Nonaka \& Takeuchi, 1995). Usually, the explicit knowing how competency for a certain job is described in individuals' job descriptions (Gunz, Evans, \& Jalland, 2000).

The effects of the knowing how competency on perceived work performance have been identified in many previous studies. Theoretically, the positive effects of the knowing how competency are based on discussion of the human capital. Suutari and Mäkelä (2007) found that the knowing how career competency enhances work performance. Eby, Butts, and Lookwood (2003) also found that the knowing how competency, including career-related skills and career identity, have positive effects on perceived career success. Especially, such study found that the knowing how competency has a larger influence on perceived external marketability than the knowing why and knowing whom career competencies. Other previous studies also found that the knowing how competency (career-related skills, work exploration, career control, etc.) has a statistically significant effect on perceived work performance (Akkermans et al., 2012; Colakoglu, 2011; Francis-Smythe et al., 2012). Based on the previous studies' findings, the following hypothesis was proposed in this study:

Hypothesis 2. The knowing how competency may positively influence perceived work performance.

\subsection{Knowing Whom and Work Performance}

The knowing whom competency is related to personal and professional relationships providing information and career support. This relational approach to career competency includes relationships both within and outside the organization (DeFillippi \& Arthur, 1994; Parker \& Arthur, 2000; Parker, Khapova, \& Arthur, 2009). A job needs its own knowing whom competency based on the work settings. For example, distinguished academics' knowing whom competency includes the skills or abilities of mentoring 
graduate students, networking with national and international collaborations, and building relationships with one's family members (Beigi, Shirmohammadi, \& Arthur, 2018). The target question of the knowing whom competency is "With whom do you work?" In the modern business workplace environment characterized by rapid change, developmental relationships are critical sources of information and skills for successful work performance (Chang \& Kim, 2018; Thomas \& Higgins, 1996). Like the two other career competencies, the knowing whom competency has been identified as a meaningful predictor of perceived work performance in previous studies (Burt, 2005). Colakoglu (2011) found that this career competency has significant effects on subjective career success through the mediation of career autonomy and career insecurity. In the process of developing the Career Competencies Questionnaire (CCQ), Akkermans et al. (2012) identified two specific skills or abilities falling under the knowing whom competency: networking and self-profiling. Also, they found that the knowing whom competency has a positive effect on work performance. In another study, internal and external networks showed positive effects on perceived career success and perceived internal and external marketability (Eby, Butts, \& Lockwood, 2003). Regarding the effects of the knowing whom competency on perceived work performance, the following hypothesis was suggested:

Hypothesis 3. The knowing whom competency may positively influence perceived work performance.

\subsection{Career Competency and Work Performance}

The three aforementioned career competencies have relationships with one another (Arthur, Khapova, \& Richardson, 2017; DeFillippi \& Arthur, 1994). In other words, they affect one another. Previous studies have identified this interdependency using various samples (Beigi, Nayyeri, \& Shirmohammadi, 2020; Beigi, Shirmohammadi, \& Arthur, 2018; Colakoglu, 2011; Dickmann \& Harris, 2005; Dickmann \& Mills, 2010; Zikic \& Ezzedeen, 2015). Through this interdependency among the three career competencies, career capital can be accumulated. The accumulated career capital can then be used as the foundation of work performance.

The positive effects of the three career competencies on work performance have already been hypothesized in this study, as shown in the previous sections. The influence of each of these competencies may have a relative importance for individuals' perceived work performance. If the relative importance of each competency in predicting work performance can be acquired, human resource development or management practitioners may be able to use such information in allocating resources or developing strategies. A previous study has already investigated the relative importance of each of the career competencies based on the three ways of knowing (Eby, Butts, \& Lockwood, 2003). This study added one more hypothesis, as follows, and the research model of this study was also described in Figure 1:

Hypothesis 4. The three career competencies have different levels of importance for perceived work performance.

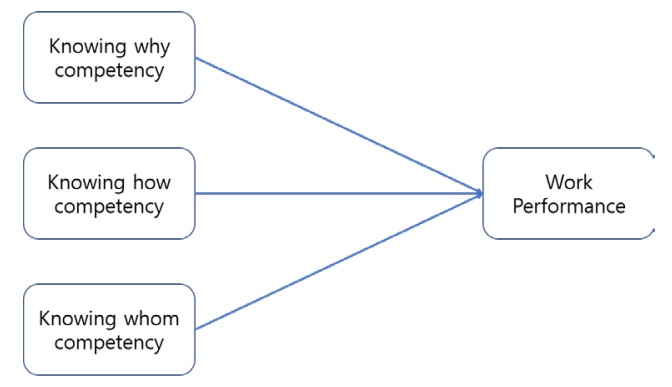

Figure 1: Research model

\section{Methods}

\subsection{Participants}

The study participants were selected from among the employees of a South Korean company in the financial service industry. For collecting data, this study used the questionnaire survey method. A total of 400 survey questionnaire sheets were distributed to randomly selected research samples with the help of the target company's human resource manager, and 291 employees in all participated in the survey. The cases with missing data and outliers were identified and excluded from the analyses. After the exclusion of the cases with missing data and outliers, the final research data were obtained from 283 cases. The final valid response rate was $70.8 \%$, which was adequate for analyzing the survey results based on the research hypotheses.

The final research data were obtained from 158 males $(55.8 \%)$ and 125 females $(44.2 \%)$. The average age was $33.8(S D=5.4)$. In terms of the highest education level, $8.8 \%(n=25)$ of the survey respondents had a 2 -year college degree, $59.4 \%(n=168)$ had a 4-year college degree, and $31.8 \%(n=90)$ had a postgraduate degree. Regarding the job position, 180 participants $(63.6 \%)$ had a under managerial position. The organizational tenure ranged from 1 to 19 years, with an average of 7.4 years $(S D=6.2)$. 


\subsection{Instruments}

This study encompassed three measures of career competency: knowing why, knowing how, and knowing whom. These three career competencies were used as the independent variables in this study. The career competencies were measured using the Career Competencies Questionnaire (CCQ) developed by Akkermans et al. (2012). Akkermans et al. suggested a framework after investigating the various perspectives on career competencies. Their model consisted of three dimensions: reflective career competencies, behavioral career competencies, and communicative career competencies (Akkermans et al., 2012). According to them, these three dimensions are compatible with the knowing why, knowing whom, and knowing how competencies, respectively. Also, each dimension consisted of two career competencies.

First, the knowing why competency was measured based on reflection on motivation (three items, defined as "reflecting on values, passions, and motivations with regard to one's personal career"; e.g., "I know what I like in my work") and reflection on qualities (four items, defined as "reflecting on strengths, shortcomings, and skills with regard to one's personal career"; e.g., "I know my strengths in my work"). The reliability coefficient of these two competencies were .83 and .79 , respectively.

Second, the knowing how competency was measured based on work exploration (three items, defined as "actively exploring and searching for work-related and career-related opportunities on the internal and external labor market"; e.g., "I am able to explore my possibilities on the labor market") and career control (four items, defined as "actively influencing learning processes and work processes related to one's personal career by setting goals and planning how to fulfill them"; e.g., "I know what I want to have achieved in my career a year from now"). The reliability coefficient of these two competencies were .75 and .78 , respectively.

Third, the knowing whom competency was measured based on networking (four items, defined as "the awareness of the presence and professional value of an individual network, and the ability to expand this network for careerrelated purposes"; e.g., "I know a lot of people within my work who can help me with my career") and self-profiling (three items, defined as "presenting and communicating personal knowledge, abilities and skills to the internal and external labor market"; e.g., "I can show the people around me what is important to me in my work"). The reliability coefficient of these competencies were .75 and .81 , respectively. To sum up, the knowing why, knowing how, and knowing whom competencies were measured through 21 questionnaire items based on six sub-competencies (Akkermans et al., 2012).
To measure the perceived individual work performance, five questionnaire items developed by Babin and Boles (1996) were used in this study. Satisfactory reliability coefficients $(\alpha=87)$ were shown for these five items. All the questionnaire items used 5-point Likert scale. The original questionnaire items were written in English; thus, the survey items were translated into Korean.

\subsection{Analysis}

After the descriptive and correlation analyses, partialcorrelation analysis was done to identify the effects of the independent variables (career competencies) on the dependent variable (perceived work performance). Dominance analysis was also conducted to identify the importance of each career competency. For the dominance analysis, this study followed Budescu's (1993) suggestion. Dominance analysis is an alternative method of the traditional multiple regression analysis, whose results can be different based on the entry order of the predictors. Without a clear theoretical foundation on the relative importance of the predictors, the traditional regression analysis may provide incorrect information about the predicting power of the independent variables (Cohen \& Cohen, 1983). To overcome this limitation, the dominance analysis method utilizing the average variance accounted for by each predictor in all the regression analyses based on the combinations of predictors in such analyses was used (Darlington \& Hayes, 2016). This dominance analysis method is used in several academic fields to determine the relative importance of factors (Mellard, Anthony, \& Woods, 2012; Morrow et al., 2010; Vize et al., 2017). Even in career competency studies, this method has been used (Eby, Butts, $\&$ Lockwood, 2003). For the analysis of the results of this study, the SPSS 21.0 statistical software was used.

\section{Results}

The results of the descriptive and correlation analyses are shown in Table 1. The results show that the three career competencies based on the three ways of knowing have significant relationships with perceived individual work performance (ranging from $r=.264$ to .408 ). Regarding the positive relationships between the career competencies and perceived work performance, Table 2 shows the results of the partial-correlation. The results support the three study hypotheses regarding the positive relationship between the three ways of knowing and perceived work performance. This means that the knowing why (reflection on motivation, $r=.265$; reflection on qualities, $r=.308$ ), knowing how (work exploration, $r=.210$; career control, $r=.241$ ), and knowing whom (networking, $r=.305$; self-profiling, $r=.281$ ) competencies are all significantly positively related to perceived work performance. 
Table 1: Descriptive and Correlation Analysis Results

\begin{tabular}{|l|c|c|c|c|c|c|c|c|c|}
\hline & $\mathbf{M}$ & SD & $\mathbf{1}$ & $\mathbf{2}$ & $\mathbf{3}$ & $\mathbf{4}$ & $\mathbf{5}$ & $\mathbf{6}$ & $\mathbf{7}$ \\
\hline Reflection on motivation & 3.80 & .62 & - & & & & & & \\
\hline Reflection on qualities & 4.12 & .63 & $.412^{*}$ & - & & & & & \\
\hline Work exploration & 3.89 & .78 & $.264^{*}$ & $.289^{*}$ & - & & & & \\
\hline Career control & 3.62 & .75 & $.362^{*}$ & $.365^{*}$ & $.482^{*}$ & - & & & \\
\hline Networking & 3.87 & .64 & $.410^{*}$ & $.520^{*}$ & $.273^{*}$ & $.386^{*}$ & - & & \\
\hline Self-profiling & 3.42 & .81 & $.238^{*}$ & $.467^{*}$ & $.221^{*}$ & $.324^{*}$ & $.612^{*}$ & - & \\
\hline $\begin{array}{l}\text { Perceived work } \\
\text { performance }\end{array}$ & 3.92 & .84 & $.265^{*}$ & $.408^{*}$ & $.264^{*}$ & $.302^{*}$ & $.398^{*}$ & $.348^{*}$ & - \\
\hline
\end{tabular}
" $p<.05$

Table 2: Partical correlation analysis results

\begin{tabular}{|l|l|c|}
\hline $\begin{array}{c}\text { Three ways } \\
\text { of knowing }\end{array}$ & Career competency & $\begin{array}{c}\text { Perceived work } \\
\text { performance }\end{array}$ \\
\hline \multirow{2}{*}{ Knowing why } & $\begin{array}{l}\text { Reflection on } \\
\text { motivation }\end{array}$ & $.265^{* * *}$ \\
\cline { 2 - 3 } & Reflection on qualities & $.308^{* * *}$ \\
\hline \multirow{2}{*}{ Knowing how } & Work exploration & $.210^{* * *}$ \\
\cline { 2 - 3 } & Career control & $.241^{* * *}$ \\
\hline \multirow{2}{*}{$\begin{array}{l}\text { Knowing } \\
\text { whom }\end{array}$} & Networking & $.305^{* * *}$ \\
\cline { 2 - 3 } & Self-profiling & $.281^{* * *}$ \\
\hline
\end{tabular}

${ }^{* * *} \mathrm{p}<.001$

Note: Gender, job position level, education background, and age were controlled for all the correlation analyses.

Table 3: Dominance analysis results for perceived performance

\begin{tabular}{|l|c|c|c|c|}
\hline \multirow{2}{*}{ Predictors } & \multicolumn{4}{|c|}{ Additional contribution } \\
\cline { 2 - 5 } & $\mathbf{R}^{2}$ & Why & How & Whom \\
\hline No predictors & - & .273 & .192 & .256 \\
\hline Knowing why & .273 & - & .019 & .109 \\
\hline Knowing how & .192 & .120 & - & .098 \\
\hline Knowing whom & .256 & .060 & .020 & - \\
\hline $\begin{array}{l}\text { Knowing why \& } \\
\text { knowing how }\end{array}$ & .292 & - & - & .012 \\
\hline $\begin{array}{l}\text { Knowing why \& } \\
\text { knowing whom }\end{array}$ & .298 & - & .012 & - \\
\hline $\begin{array}{l}\text { Knowing how \& } \\
\text { knowing whom }\end{array}$ & .252 & .042 & - & - \\
\hline $\begin{array}{l}\text { All three } \\
\text { predictors (total } \\
\left.R^{2}\right)\end{array}$ & .334 & - & - & - \\
\hline
\end{tabular}

Note: In all the regression equations, the gender, job position level, education background, and age variables were controlled.
The dominance analysis results are provided in Table 3 and 4. Each of the knowing why, knowing how, and knowing whom competencies refer to a set of two career competencies. Table 3 shows that the knowing why competency has a greater influence on perceived work performance (.273) than the knowing how and knowing whom competencies (.192 and .256, respectively). In other words, the knowing why competency is dominant compared to the two other career competencies. The influence levels of all the possible combinations of the independent variables for predicting perceived work performance are also shown in Table 3.

Table 4 presents the quantitative dominance analysis results of this study. Of the total variance accounted for by all the variables $\left(\mathrm{R}^{2}=.334\right.$, including the covariates), the knowing why competency (average $\mathrm{R}^{2}=.135$ ) provides the biggest contribution in the prediction, followed by the knowing whom (average $\mathrm{R}^{2}=.124$ ) and knowing how (average $\mathrm{R}^{2}=.075$ ) competencies. For each of the competencies based on the different ways of knowing, the average $R^{2}$ values are shown in the line of $M(C x i)$. Regarding the percentage of relative importance of each competency, the knowing why competency accounts for $40.4 \%$ of the full model composed of the three career competencies, and the knowing how and knowing whom competencies account for 22.5 and $37.1 \%$, respectively.

Table 4: Summary of dominance analysis

\begin{tabular}{|l|c|c|c|}
\hline $\begin{array}{c}\text { k (number of } \\
\text { additional predictors) }\end{array}$ & Why & How & Whom \\
\hline 0 & .273 & .192 & .256 \\
\hline 1 & .090 & .020 & .104 \\
\hline 2 & .042 & .012 & .012 \\
\hline$M(C x i)$ & .135 & .075 & .124 \\
\hline Relative percentage & 40.4 & 22.5 & 37.1 \\
\hline
\end{tabular}

Note: (1) In all the regression equations, the gender, job position level, education background, and age variables were controlled.

(2) M(Cxi) indicates the average usefulness of each predictor. Relative percentage in the last line shows the relative importance of each career competency. 


\section{Discussion and Conclusion}

This study tried to determine the effects of the three modern career competencies on perceived work performance, and the importance of each competency in predicting the perceived individual work performance. The study results showed that the intelligent career competency model based on the three ways of knowing is appropriate for predicting perceived work performance. The study results support all the hypotheses regarding the effects of the three career competencies on perceived work performance. The results of the dominance analysis showed the relative prediction effectiveness power of each of the three career competencies on the dependent variable, and showed that the knowing why and knowing whom competencies have a greater influence on perceived work performance than the knowing how competency. This result also supports the last hypothesis.

Regarding the effects of the knowing why competency on perceived work performance, the study results showed that this career competency has a statistically significant effect. The knowing why competency accounts for $40.4 \%$ of the total variance of the full model based on the three career competencies that was used in this study. This is consistent with the results of the previous studies that showed the positive effects of the knowing why competency on subjective career success (Colakoglu, 2011; Eby, Butts, \& Lockwood, 2003), internal marketability (Eby, Butts, \& Lockwood, 2003), task performance (Akkermans et al., 2012), and income (FrancisSmythe et al., 2012). The positive effect of the knowing why competency on perceived work performance was shown in this study.

The study results also support the hypothesis regarding the positive influence of the knowing how competency on perceived work performance. The knowing how competency is related to "career-relevant" job-related knowledge and skills (Bird, 1996; DeFillippi \& Arthur, 1994). Even though the effect of the knowing how competency is the least among the three career competencies in this study, its positive effects are comparable to those in the previous studies. For example, Eby, Butts, and Lockwood (2003) identified that the knowing how competency has the greatest effect on perceived external marketability among all the career competencies. Also, Suutari and Mäkelä (2007) conceptually argued that the skills or abilities falling under the knowing how competency, such as employability or awareness of one's career capital, have effects on perceived work performance. These study results agree with the previous studies' arguments.

The career competency related to networking and establishing connections with others was also identified in this study as a meaningful predictor of perceived work performance. The level of influence of this career competency on perceived work performance is similar to that of the knowing why competency $(37.1 \%$ of the total variance of the full model based on the three career competencies). As for the importance of the knowing whom competency in predicting perceived work performance, it has been discussed in the previous studies (Akkermans et al., 2012; Colakoglu, 2011), and the present study's results support those of the previous studies, even presenting new evidences from the South Korean sample in the financial industry.

Lastly, the dominance analysis in the present study showed that the three career competencies have different levels of importance for perceived work performance. That is, the effects of the knowing why and knowing whom competencies are larger than the effect of the knowing how competency. These results are very similar to the dominance analysis results of the career competencies in a study with U.S. university alumni as study participants (Eby, Butts, \& Lockwoods, 2003) and in a study with South Korean school teachers as study participants. These previous studies showed that the influence of the knowing why and knowing whom competencies is larger than that of the knowing how competency. The results of the present study thus support the hypothesis related to the importance of career competencies in predicting perceived work performance.

This study's investigation of the three modern career competencies provides several theoretical and practical implications. First, this study provided evidence of the appropriateness of the career capital model in the international context. The career capital model has been discussed mostly in Western countries where career capitalism is an acceptable concept. This study found the possibility of applying the model to other career environments, such as those with a cultural context, as in the East Asian region. Second, the study results showed the appropriateness of the intelligent career competency model in the current career environment. Especially, this study investigated the effects of the modern career competencies on perceived work performance, and the results showed the significant effects of such competencies. This highlighted the appropriateness of the model in the modern career era and in the current business setting.

Third, this study showed an empirical evidence of the validity of the career capital model, which is an important contribution considering that there are few empirical studies explaining such model. Also, the method that was employed in this study, dominance analysis, showed an alternative way of assessing the meaningfulness of the career capital model in the current career environment. Even in other research settings, the research method that was employed in this study may be used to find the importance of each predictor to the dependent variable.

Lastly, this study's results may provide practical suggestions for assigning resources for the acquisition of career competencies by the research population in the financial industry. The study results showed that the knowing why and knowing whom competencies have similar levels 
of influence on perceived work performance, and that the knowing how competency has a smaller influence than the two other career competencies. Organizations usually provide their employees with resources for enhancing their job-related knowledge and skills, which can be categorized as the knowing how competency. This study, however, suggests other strategies for investing in resources for organizational employees. Especially, the importance of the knowing why and knowing whom competencies highlighted in this study can be an empirical evidence for the appropriate future strategic human resource management and development approaches.

Even though this study suggested several meaningful theoretical and practical implications, it has some limitations. Firstly, this study results can be applied only to the employees in the South Korean financial industry. Therefore, the relative importance of each career competency for perceived work performance needs to be understood by human resource scholars and practitioners considering this limitation. Furthermore, the financial industry is a very specific and rapidly changing area based on the business workplace environment, and the main service and product of the present study's target organization is personal banking. The generalization of the study results should thus be considered in the future research work.

The other limitation is related to the process of career capital accumulation. This study introduced an intelligent career model consisting of three career competencies. Even though the research method that was employed in this study, dominance analysis, is useful in determining how important each career competency is for perceived work performance, the whole process of career competency or capital accumulation may not be captured through it. The use of other instruments related to the process of career competency or capital development, or of a mixed method employing both quantitative and qualitative approaches, may make up for this limitation.

Lastly, this study measured work performance based on the individual's perception. This subjective perceived work performance may be different from the real or actual work performance, which is directly related to organizational success. To address this limitation, the future studies should be designed to use a different study method employing both quantitative and qualitative approaches for identifying statistical significance, to have more varied research participants, and to include objective criteria for evaluating work performance.

\section{References}

Akkermans, J., Brenninkmeijer, V., Huibers, M., \& Blonk, R. W. B. (2012). Competencies for the contemporary career: Development and preliminary validation of the career competencies questionnaire. Journal of Career Development, 40(3), 245-267.

Ahn, S., \& Park, C. (2016). An empirical study on eliciting a competency required by salespeople: Differentiating B2B salespeople and B2C salespeople. Journal of Distribution Science, 14(11), 103-115.

Arthur, M. B., \& Rousseau, D. M. (1996). The Boundaryless Career: A New Employment Principle for A New Organizational Era. New York, NY: Oxford University Press.

Arthur, M. B., Claman, P. H., \& DeFillippi, R. J. (1995). Intelligent enterprise, intelligent careers. Academy of Management Executive, 9(4), 7-22.

Arthur, M. B., Inkson, K., \& Pringle, J. K. (1999). The New Careers: Individual Action \& Economic Change. London, UK: Sage.

Arthur, M. B., Khapova, S. N., \& Richardson, J. (2017). An Intelligent Career: Taking Ownership of Your Work and Your Life. London, UK: Oxford University Press.

Babin, B. J., \& Boles, J. S. (1996). The effects of perceived coworker involvement and supervisor support on service provider role stress, performance and job satisfaction. Journal of Retailing, 72(1), 57-75.

Beigi, M., Nayyeri, S., \& Shirmohammadi, M. (2020). Driving a career in Tehran: Experiences of female internet taxi drivers. Journal of Vocational Behavior, 116, Part A, 103347.

Beigi, M., Shirmohammadi, M., \& Arthur, M. (2018). Intelligent career success: The case of distinguished academics. Journal of Vocational Behavior, 107, 261-275.

Bird, A. (1996). Careers as repositories of knowledge: Considerations for boundaryless careers. In M. B. Arthur, \& D. M. Rousseau (Eds.), The Boundaryless Career: A New Employment Principle in A New Organizational Era (pp.150168). New York, NY: Oxford University Press.

Budescu, D. V. (1993). Dominance analysis: A new approach to the problem of relative importance of predictors in multiple regression. Psychological Bulletin, 114(3), 542-551.

Burt, R. S. (2005). Brokerage and Closure: An Introduction to Social Capital. Oxford, UK: Oxford University Press.

Cappellen, T., \& Janssens, M. (2005). Career paths of global managers: Towards future research. Journal of World Business, 40(4), 348-360.

Chang, J., \& Kim, T. (2018). Looking at organizational socialization from the developmental network perspective. Journal of Asian Finance, Economics and Business, 5(3), 195-206.

Cohen, J., \& Cohen, P. (1983). Applied Multiple Correlation/ Regression. Hillsdale, NJ: Lawrence Erlbaum.

Colakoglu, S. N. (2011). The impact of career boundarylessness on subjective career success: The role of career competencies, career autonomy, and career insecurity. Journal of Vocational Behavior, 79(1), 47-59.

Darlington, R. B., \& Hayes, A. F. (2016). Regression Analysis and Linear Models. New York, NY: Guilford Publications. 
DeFillippi, R. J., \& Arthur, M. B. (1994). The boundaryless career: A competency-based perspective. Journal of Organizational Behavior, 15, 307-324.

DeFillippi, R. J., \& Arthur, M. B. (1996). Boundaryless contexts and careers: A competency-based perspective. In M. B. Arthur, \& D. M. Rousseau (Eds.), The Boundaryless Career: A New Employment Principle in A New Organizational Era (pp.116131). New York, NY: Oxford University Press.

Dickmann, M., \& Harris, H. (2005). Developing career capital for global careers: The role of international assignments. Journal of World Business, 40(4), 399-408.

Dickmann, M., \& Mills, T. (2010). The importance of intelligent career and location considerations: Exploring the decision to go to London. Personal Review, 39(1), 116-134.

Eby, L. T., Butts, M., \& Lockwood, A. (2003). Predictors of success in the era of the boundaryless career. Journal of Organizational Behavior, 24(6), 689-708.

Francis-Smythe, J., Haase, S., Thomas, E., \& Steele, C. (2012). Development and validation of the career competencies indicator (CCI). Journal of Career Assessment, 21(2), 227-248.

Gunz, H., Evans, M., \& Jalland, M. (2000). Career boundaries in a boundaryless world. In M. Peiperl, M. Arthur, R. Goffee, \& T. Morris (Eds.), Career Frontiers (pp.24-53). Oxford, UK: Oxford University Press.

Hall, D. T. (2002). Careers in and out of Organizations. Thousand Oaks, CA: Sage.

Hall, D. T. (2004). The protean career: A quarter-century journey. Journal of Vocational Behavior, 65(1), 1-13.

Inkson, K., \& Arthur, M. B. (2001). How to become a successful career capitalist. Organizational Dynamics, 30(1), 48-61.

Jones, C., \& DeFillippi, R. (1996). Back to the future in film: Combining industry and self knowledge to meet the career challenges of the 21st Century. Academy of Management Executive, 10(4), 89-104.

Jones, C., \& Lichtenstein, B. (2000). The architecture of careers: How career competencies reveal firm dominant logic in professional services. In M. Peiperl, M. Arthur, R. Goffee, \& T. Morris (Eds.), Career Frontiers (pp.153-176). Oxford, UK: Oxford University Press.

Kang, Y., Lee, S., Moon, J., \& Chang, J. (2016). The effects of perceived organizational support on subjective career success: The mediating effect of career planning. Journal of Distribution Science, 14(2), 83-92.

Kuijpers, M. A. C. T., Schyns, B., \& Scheerens, J. (2006). Career competencies for career success. Career Development Quarterly, 55(2), 169-179.

Lee, W.-S., \& Kim, B.-Y. (2019). The effects of career orientations on entrepreneurial satisfaction and business sustainability. Journal of Asian Finance, Economics and Business, 6(4), 235-248.
Lichtenstein, B., \& Mendenhall, M. (2002). Non-linearity and response-ability: Emergent order in 21 st century careers. Human Relations, 55(1), 5-32.

Lips-Wiersma, M., \& Hall, D. T. (2007). Organizational career development is not dead: A case study on managing the new career during organizational change. Journal of Organizational Behavior, 28(6), 771-792.

Mainiero, L. A., \& Sullivan, S. E. (2005). Kaleidoscope careers: An alternate explanation for the "opt-out" revolution. Academy of Management Executive, 19(1), 106-123.

Mellard, D. F., Anthony, J. L., \& Woods, K. L. (2012). Understanding oral reading fluency among adults with low literacy: Dominance analysis of contributing component skills. Reading and Writing: An Interdisciplinary Journal, 25(6), 1345-1364.

Morrow, S. L., McGonagle, A. K., Dove-Steinkamp, M. L., Walker, C. T., Marmet, M., \& Barnes-Farrell, J. L. (2010). Relationships between psychological safety climate facets and safety behavior in the rail industry: A dominance analysis. Accident Analysis and Prevention, 42(5), 1460-1467.

Nonaka, I., \& Takeuchi, H. (1995). The knowledge-creating Company. New York, NY: Oxford University Press.

Park, H., \& Park, H. (2019). The effect of efficiency evaluation on the organizational effectiveness of the cabin crew's competency. Journal of Distribution Science, 17(7), 5-13.

Parker, P., \& Arthur, M. B. (2000). Careers, organizing, and community. In M. Peiperl, M. Arthur, R. Goffee, \& T. Morris (Eds.), Career Frontiers (pp.99-121). Oxford, UK: Oxford University Press.

Parker, P., Khapova, S. N., \& Arthur, M. B. (2009). The intelligent career framework as a basis for interdisciplinary inquiry. Journal of Vocational Behavior, 75(3), 291-302.

Quinn, J. B. (1992). Intelligent Enterprise. New York, NY: Free Press.

Sturges, J., Simpson, R., \& Altman, Y. (2003). Capitalising on learning: An exploration of the MBA as a vehicle for developing career competencies. International Journal of Training and Development, 7(1), 53-66.

Suutari, V., \& Mäkelä, K. (2007). The career capital of managers with global careers. Journal of Managerial Psychology, 22(7), 628-648.

Thomas, D., \& Higgins, M. (1996). Mentoring and the boundaryless career: Lessons from the minority experience. In M. B. Arthur, \& D. M. Rousseau (Eds.), The Boundaryless Career: A New Employment Principle in a New Organizational Era (pp.268281). New York, NY: Oxford University Press.

Vize, C. E., Collison, K. L., Crowe, M. L., Campbell, W. K., Miller, J. D., \& Lynam, D. R. (2019). Using dominance analysis to decompose narcissism and its relation to aggression and externalizing outcomes. Assessment, 26(2), 260-270. 
Wrzesniewski, A. (2002). It's not just a job: Shifting meaning of work in the wake of 9/11. Journal of Management Inquiry, 11(3), 230-234.

Yoon, K.-H., \& Kim, B.-Y., \& Eom, J.-G. (2019). The effects of job crafting on career success of multinational corporation's employees. Journal of Asian Finance, Economics and Business, 6(4), 213-225.
Zikic, J., \& Ezzedeen, S. (2015). Towards a more integrated view of entrepreneurial careers: Qualitative investigation of the three forms of career capital and their relationships among high tech entrepreneurs. International Journal of Entrepreneurial Behavior \& Research, 21(6), 756-777. 